\title{
Phytophthora kernoviae isolated from fallen leaves of Drymis winteri in native forest of southern Chile
}

\author{
E. Sanfuentes ${ }^{1} \cdot$ S. Fajardo ${ }^{1} \cdot$ M. Sabag $^{1} \cdot$ E. Hansen $^{2} \cdot$ M. González $^{3}$
}

Received: 21 January 2015 / Accepted: 9 May 2016 / Published online: 17 May 2016

(C) Australasian Plant Pathology Society Inc. 2016

\begin{abstract}
Phytophthora kernoviae is an invasive species first described from Britain and later New Zealand. We conducted surveys for Phytophthora species in forests in southern Chile. Symptomatic fallen leaves of Drimys winteri were encountered in a native forest. P. kernoviae was isolated. This is the first report of $P$. kernoviae outside of UK and New Zealand.
\end{abstract}

Keywords Phytophthora in native forest - Drimys winteri . Phytophthora kernoviae

Surveys for the presence of Phytophthora species in Chilean forest trees were conducted in May and December 2012 in southern Chile. Fallen leaves of "canelo" (Drimys winteri) (Winteraceae) with necrosis around the midrib (Fig. 1) were encountered in a native evergreen forest near the city of Valdivia, Región de Los Ríos (3950' 26, 731'”; 7307’30, $\left.617^{\prime \prime}\right)$. Samples of leaves still attached to the plant, leaves recently fallen on the surface of the forest floor, semidecomposed leaf litter and mineral soil to $20 \mathrm{~cm}$ deep were brought to laboratory. Leaf litter and mineral soil were placed in plastic tubs with $150 \mathrm{~mL}$ sterile distilled water (SDW), covered with a plastic mesh and incubated for $24 \mathrm{~h}$ at $16^{\circ} \mathrm{C}$ under continuous light. Healthy leaves of canelo baits were then

E. Sanfuentes

esanfuen@udec.cl

1 Laboratorio de Patología Forestal, Facultad Ciencias Forestales y Centro de Biotecnología, Universidad de Concepción, Concepción, Chile

2 Department of Botany and Plant Pathology, Oregon State University, Cordley Hall 2082, Corvallis, OR 97331-2902, USA

3 Biocaf S. A., Camino a Coronel Km 15, Concepción, Chile floated over the plastic mesh and incubated for seven days at $16{ }^{\circ} \mathrm{C}$ under white light. After incubation, the leaf baits were surface sterilized (20 min under running tap water, ethanol $70 \%$ for $30 \mathrm{~s}$ followed by three consecutive washes under SDW). After blotting dry the leaves used as baits were cut into $1 \times 0.5 \mathrm{~cm}$ pieces and transferred to CARNH (Corn meal agar $17 \mathrm{~g} / \mathrm{L}$, ampicillin $300 \mu \mathrm{g} / \mathrm{ml}$, rifampicin $15 \mu \mathrm{g} / \mathrm{ml}$, natamicin $15 \mu \mathrm{g} / \mathrm{ml}$ and hymexazol $50 \mu \mathrm{g} / \mathrm{ml}$ ) and incubated seven days at $20{ }^{\circ} \mathrm{C}$ in darkness.

Direct isolation from leaves of canelo still attached to the plant and recently fallen leaves recovered from the leaf litter showing necrosis was also attempted. Leaves with necrotic areas were surface sterilized as above. After blotting dry in a laminar flux chamber the leaves were cut into small pieces $(1 \times 0.5 \mathrm{~cm})$ including healthy and necrotic tissues and seeded on CARNH plates.

Two Phytophthora-like were obtained. One isolate (Isolate LV) was obtained directly from lesions on a fallen leaf; the other isolate (Isolate H2) was obtained from baited leaves. No isolates were obtained from leaves that were still attached to canelo trees. Both colonies exhibited a petaloid-star form on carrot agar, but on potato dextrose agar (Difco) the colonies were distinctly petaloid. The sporangia, formed directly from the leaves and from mycelial discs in soil extract (Jeffers and Aldwinckle 1987) were deciduous with short pedicles, papillate, with an average of $39,4 \mu \mathrm{m}( \pm 8,17)$ in length and 25 , $8 \mu \mathrm{m}( \pm 6,35)$ in width (ranges from 23.1-61.9 $\mu \mathrm{m}$ long and 19.3-35.1 um wide) (Fig. 2). Also, occasional mouse- shaped sporangia were founded. The isolates were homothallic, forming abundant oogonia on Hemp Seed Agar (Satour and Butler 1967) and infrequently within the leaves. Oogonial diameters averaged 23,7 $\mu \mathrm{m}( \pm 3,22)$ (range 15.6-30.0 $\mu \mathrm{m})$. Antheridia were amphigynous of average length of $12,45 \mu \mathrm{m}$ $( \pm 1,5)$ and width $10,8( \pm 1,45)$ (ranging from 9.2-16.6 to 7.9$14.8 \mu \mathrm{m}$, respectively). The oospores were plerotic and 
Fig. 1 Leaves of Drimys winteri in the litterfall showing necrosis around the midrib a a leaf with the similar type of necrosis still attached a shoot $\mathbf{b}$
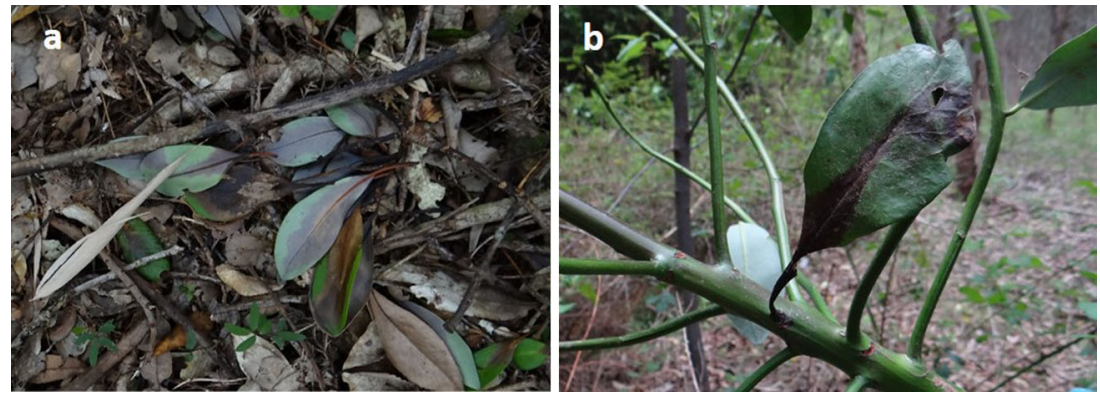

averaged $21,73 \mu \mathrm{m}( \pm 3,45)$ in diameter with a range of ca 13.0-28.7 $\mu \mathrm{m}$. Overall the morphological characteristics matched those described for P. kernoviae (Brasier et al. 2005) including oogonia with tapered stalks, amphigynous antheridia, and mostly lemon-shaped sporangia (occasionally "mouse-shaped") with short sporangial pedicels.

Molecular identification was performed using mycelium from a seven day old culture on carrot agar to extract genomic DNA (Axyprep multisource genomic DNA miniprep, Union City, CA, USA). Yph1f (5' CGA CCA TKG GTG TGG ACT TT 3') and Yph2R (5' ACG TTC TCM CAG GCG TAT CT 3') primers were used for the amplification of the YPt1 (ras-related protein) according to the methods of Schena et al. (2006). The PCR conditions were: 2 min at $95^{\circ} \mathrm{C}$, followed by 35 cycles for 30 s at $94{ }^{\circ} \mathrm{C}, 30$ s at $55^{\circ} \mathrm{C}$ and $1 \mathrm{~min}$ at $72{ }^{\circ} \mathrm{C}$, finally $72^{\circ} \mathrm{C}$ for $10 \mathrm{~min}$. The PCR products were then sequenced by MACROGEN (Korea) and compared with Phytophthora spp. sequences available in Genbank with BLAST (http://www. ncbi.nlm.nih.gov/BLAST/).

The Ypt1 sequence for both Phytophthora isolates, $\mathrm{H} 2$ and LV, was 99-100\% identical with the sequences of P. kernoviae strains SCRP957 from Fagus sylvatica and
Fig. 2 Phytophthora kernoviae isolates LV and $\mathrm{H} 2$. Upper row: typical caducous papillate sporangia formed by $P$. kernoviae isolates. Lower row: Plerotic oospores with amhigynous antheridia formed in infected leaves on Hemp seed agar

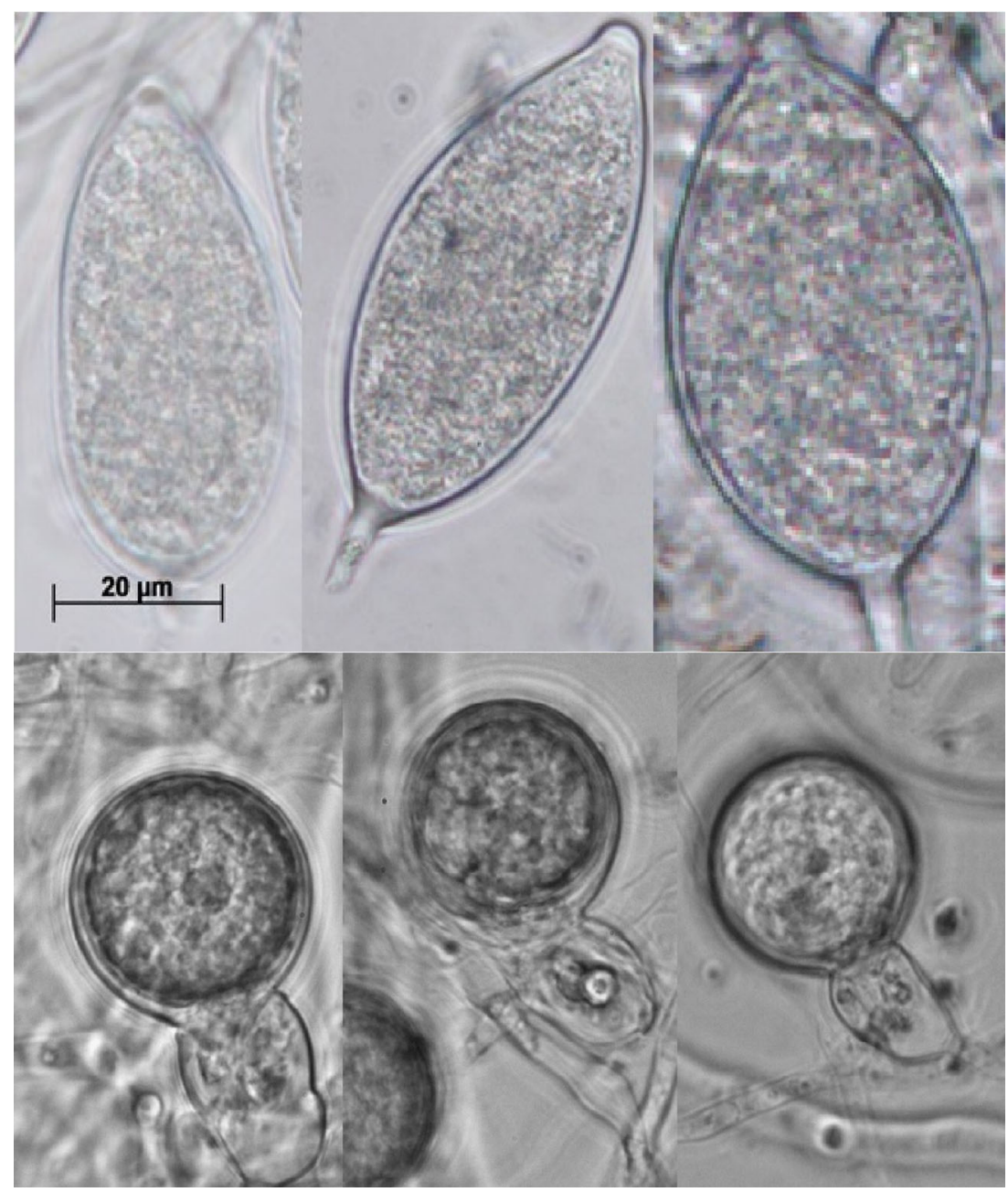


Fig. 3 Non-wounded Drimys winteri leaves inoculated with Phytophthora kernoviae zoospore suspension, showing necrosis

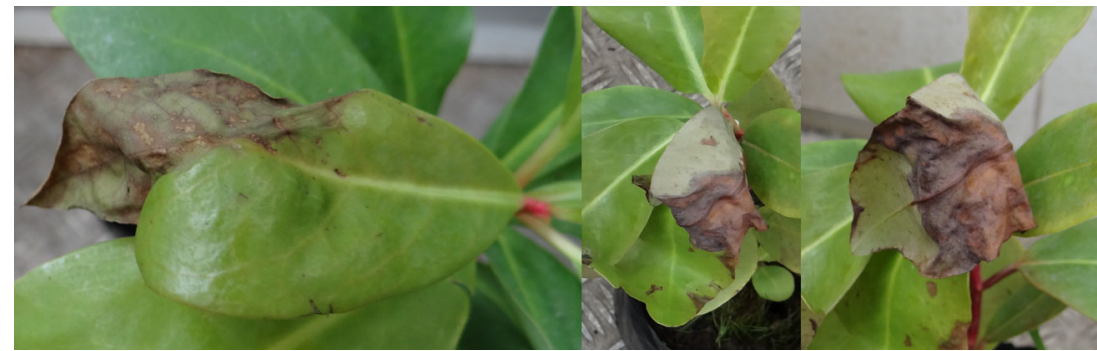

KER-CSL from England (Schena et al. 2006). Sequences of both isolates were deposited in GenBank, accessions KJ628094 (isolate H2) and KJ628095 (isolate LV). Both $P$. kernoviae isolates were deposited in the International collection of microorganism from plants (ICMP), with code numbers 20,923 (isolate H2) and 20,924 (isolate LV), respectively.

Two pathogenicity tests were performed on healthy sixmonth old canelo plants obtained from a commercial forest nursery. First, detached canelo leaves were surface sterilized as above and placed in plastic tubs over a wet paper towel. Mycelial discs $(1 \mathrm{~cm})$ of isolate $\mathrm{H} 2$ cut from actively growing colonies on carrot agar ( 7 days at $20^{\circ} \mathrm{C}$ in darkness) were used as inoculums. Single mycelial discs were placed on the abaxial sides of ten canelo leaves and incubated for 7 days at $16^{\circ} \mathrm{C}$ in continuous white light. Sterile carrot agar discs were used as controls. Second, canelo plants were inoculated by leaf immersion in a zoospore suspension (Fichtner et al. 2012). For zoospore production, isolate $\mathrm{H} 2$ was grown on carrot agar for 10-15 days at $16^{\circ} \mathrm{C}$ under continuous white light. $30 \mathrm{ml}$ of SDW was then added and the colonies gently scraped with a Pasteur pipette to liberate sporangia. The sporangial suspension was filtered to eliminate any remaining mycelium and incubated for $45 \mathrm{~min}$ at $4{ }^{\circ} \mathrm{C}$ to liberate the zoospores. A final zoospore concentration of $2.3 \times 10^{6}$ zoospore/ml was obtained. Attached non wounded leaves and leaves wounded by cutting $25 \%$ of the leaf apical section were inoculated by submerging $50 \%$ of the leaf for $6 \mathrm{~h}$ in Falcon tubes containing $30 \mathrm{ml}$ of zoospore suspension. After inoculation, leaf surface wetness was maintained by covering the plants with plastic bags for $48 \mathrm{~h}$. The plants were kept at $16{ }^{\circ} \mathrm{C}$ with a $12 \mathrm{~h}$ light/ dark photoperiod. Symptom appearance was evaluated and pathogenicity was confirmed by the re-isolation of the pathogen from the wounds using methods described above.

Three days post-inoculation with mycelial discs all inoculated leaves exhibited necrotic lesions that started from the disc margin and advanced to the leaf edge. P. kernoviae was re-isolated from all the lesions.
The control leaves showed no symptoms. In the leaf immersion test, at $72 \mathrm{~h}$ post-inoculation small necrotic spots began to appear on both the wounded and non-wounded leaves. $120 \mathrm{~h}$ after inoculation, necrotic lesions were present on all non wounded inoculated leaves (Fig. 3) and in the majority of the wounded leaves. Leaves on non inoculated control plants never developed lesions. P. kernoviae was reisolated from all necrotic tissues.

This study reports for the first time the presence of $P$. kernoviae in native South American forests, obtained from necrotic lesions on fallen leaves of $D$. winteri in the surface litter. P. kernoviae was originally described as an invasive species attacking rhododendron and Fagus in Britain (Brasier et al. 2005). Its origin was unknown but Brasier et al. (2005) suggested Patagonia (South America) as a possible source. It was later discovered as a probable indigenous species in New Zealand forests (Scott and Williams 2014). It is notable that the Chilean Valdivian rain forest flora shares features of the ancient Gondwanaland flora with New Zealand, including genera in the Winteraceae.

\section{References}

Brasier CM, Beales P, Kirk S, Denman S, Rose J (2005) Phytophthora kernoviae sp. nov., an invasive pathogen causing bleeding stem lesions on forest trees and foliar necrosis of ornamentals in the UK. Mycol Res 109:853-859

Fichtner EJ, Rizzo DM, Kirk SA, Webber JF (2012) Infectivity and sporulation potential of Phytophthora kernoviae to select North American native plants. Plant Pathol 61:224-233

Jeffers SN, Aldwinckle HS (1987) Enhancing detection of Phytophthora cactorum in naturally infested soil. Phytopathology 77:1475-1482

Satour M, Butler EE (1967) A root and crown rot of tomato caused by Phytophthora capsici and P. parasitica. Phytopathology 57:510-515

Schena L, Huges K, Cooke D (2006) Detection and quantification of Phytophthora ramorum, $P$. kernoviae, $P$. citricola and $P$. quercina in symptomatic leaves by multiplex real-time PCR. Mol Plant Pathol 7:365-379

Scott P, Williams N (2014) Phytophthora diseases in New Zealand forests. New Zeal J For Sci 59:14-21 